\title{
Non-Anesthetic Effects of Ketamine: A Review Article Authors
}

\section{Jabril Eldufani ${ }^{1 *}$, Alireza Nekoui ${ }^{1}$ and Gilbert Blaise ${ }^{1,2}$}

${ }^{1}$ Department of Medicine, University de Montréal, Montreal, Quebec, Canada

${ }^{2}$ Department of Anesthesiology and Pain Management, Centre Hospitalized University de Montréal (CHUM), Montreal, Quebec, Canada

\begin{abstract}
Ketamine is considered a dissociative anesthetic medication, and it is a commonly administered by a parenteral route. It works mainly by blocking the $\mathrm{N}$-methyl-D-aspartate (NMDA) receptor. It inhibits the voltage-gated $\mathrm{Na}_{\text {_ }}$ and $\mathrm{K}$ _ channels and serotonin and dopamine re-uptake; also, it affects specific receptors, such as a-amino-3-hydroxy5-methyl-4-isoxazolepropionic acid (AMPA), kainite and amino butyric acid A receptors. Ketamine appears to have particular mechanisms that are potentially involved during analgesic induction, including enhancing of descending inhibition and anti-inflammatory effects. More recently, it has been shown that ketamine has potential in clinical practice for the management of chronic pain, cognitive function, depression, acute brain injury and disorders of the immune system.
\end{abstract}

Keywords: Ketamine; Chronic pain; N-methyl-d-aspartate receptor antagonist; Depression; Brain injury; Immune system

\section{Introduction}

Since 1970, ketamine has been clinically used as an anesthetic medication [1]. It is thought to modulate N-methyl-D-aspartate (NMDA), a-amino-3-hydroxy-5-methyl-4-isoxazolepropionic acid, kainate, and aminobutyric acid-A receptors [1,2]. Its ability to inhibit the voltage-gated $\mathrm{Na}_{-}$and $\mathrm{K}_{-}$channels and serotonin and dopamine reuptake might be useful in some clinical conditions, such as managing chronic pain, depression, acute brain injury, etc. $[1,3]$. Ketamine has been used in clinical practice in different medical specialties [4,5]. It produces a wide variety of pharmacological effects, including sedation, analgesia, bronchodilation, and sympathetic nervous system (SNS) stimulation [4,6,7]. Anesthesiologists and pain specialists have begun to use ketamine, in sub-anesthetic doses, for the long-term treatment of chronic refractory pain, particularly neuropathic pains, such as complex regional pain syndrome, post-herpetic neuralgia and diabetic neuropathic pain $[4,8,9]$.

The pharmacological and anesthetic properties of ketamine have been identified since 1965 [10]. Ketamine is known as a dissociative anesthetic agent that produces strong analgesia and amnesia $[10,11]$. In addition, it elicits a variety of side effects, such as the induction of psychedelic conditions leading to hallucinations and excitation symptoms [12,13].

In this review, we will discuss the relevant literature on the potential benefits and risks of ketamine use in pathological conditions, including managing chronic pain, cognitive function, depression, acute brain injury, and immune system disorders.

\section{Pharmacology}

Ketamine can rapidly pass the blood-brain barrier and, therefore, has a quick onset of analgesic effect [14,15]. Ketamine potentially produces an analgesic effect at several sites of the nervous system, both centrally and peripherally [16-18]. New research shows that ketamine has inhibitory effects on voltage-gated $\mathrm{Na}$ and $\mathrm{K}$ channels, serotonin receptors and it inhibits dopamine reuptake [19-21]. The mechanism of action of ketamine is thought to involve an interaction between $\mathrm{N}$-methyl-D-aspartate receptors, the nitric oxide pathway, and opioid receptors [22,23].

\section{Chronic pain}

Ketamine is administered to treat various diseases that cause chronic refractory pain, particularly those that have a neuropathic component [24]. It has recently been reported that a low intravenous dose of ketamine produces potent analgesia in neuropathic pain conditions, presumably by inhibition of the N-methyl-D-aspartate receptor [24]. However, it appears that particular mechanisms are potentially involved, including enhancing of the descending inhibition and anti-inflammatory effects [25]. In chronic pain conditions, prolonged nociceptive stimulation leads to activation and upregulation of the N-methyl-D-aspartate receptors at the dorsal horn synapses resulting in enhancing and amplifying pain signals to the brain [26]. This phenomenon would be a significant factor in the process of perseverance and eventual cornification of pain [27,28].

More recently, research has shown that N-methyl-D-aspartate receptor antagonists, such as ketamine, can halt the excessive barrage of nociceptive input to the brain and, therefore, are possible alternatives to existing therapies of chronic pain syndromes $[27,29]$. Also, there are other effects of ketamine that might contribute to its analgesic behavior by enhancing the descending inhibition pathway, especially in patients with chronic neuropathic pain [29]. Indeed, ketamine could prevent the occurrence of chronic pain conditions, such as that experienced in the postsurgical period after lower limb amputation [28]. In order to achieve adequate management of chronic pain, it is preferred to use a multimodal approach to different medications [27,28].

Several clinical studies have reported that using ketamine with morphine in the treatment of chronic cancer pain has reduced morphine consumption with less pain and fewer adverse effects [27]. Ketamine improves the efficacy of opioid treatment in chronic cancer pain during long-term management [27]. This is because ketamine's ability to reduce neuropathic pain is superior to that of opioids, but

*Corresponding author: Jabril Eldufani, MD, MSc, Department of Medicine, University de Montréal, Montreal, Quebec, 529, rue Jarry est, Bureau 400 Montréal QC, H2P 1V4 Canada Tel: +1 438-386-7882; E-mail: Jabril.Eldufani@umontreal.ca

Received April 14, 2018; Accepted April 24, 2018; Published April 27, 2018

Citation: Eldufani J, Nekoui A, Blaise G (2018) Non-Anesthetic Effects of Ketamine: A Review Article Authors. J Health Med Informat 9: 311. doi: 10.4172/2157-7420.1000311

Copyright: @ 2018 Eldufani J, et al. This is an open-access article distributed under the terms of the Creative Commons Attribution License, which permits unrestricted use, distribution, and reproduction in any medium, provided the original author and source are credited. 
it can additively and synergistically interact with opioids, probably through the descending inhibitory pathway. Some experimental studies in mice lacking $\mu$-opioid receptors have suggested a crucial role of the $\mu$-opioid receptor in ketamine-induced acute analgesia [27]. However, the inhibitory pathway of presynaptic spinal dorsal neurons would also achieve relieving acute pain $[29,30]$. The activation of N-methyl-Daspartate receptor at these presynaptic areas could lead to the release of excitatory substances, including glutamate and substance $\mathrm{P}[27,30]$.

\section{Cognitive function}

Analysis of cognitive and memory functions during short-term ketamine infusion has demonstrated impairment of working memory and reduction in the encoding of information into episodic memory. In contrast to other amnestic medications, ketamine impairs semantic memory in some patients. After the termination of short duration and single ketamine infusions, memory function reverts to a healthy state, which possibly indicates ketamine-induced memory loss is selfresolving. However, the effects on memory function of the long-term use of low-dose ketamine for the treatment of chronic pain are poorly reported and, consequently, unknown. Nevertheless, a recent clinical study that examined the safety of high-dose, long-term ketamine in complex regional pain syndrome (CRPS) patients who received anesthetic doses over 5 days demonstrated no severe cognitive defects.

The use of ketamine for neuroprotection (either intraoperatively or in the intensive care unit setting with adequate neurocognitive or neuroradiological follow-up), in clinical studies, could support the hypothesis that ketamine may protect cognitive functions [31]. One research group has been particularly interested in the potential of ketamine's neuroprotection mechanism to alleviate postoperative cognitive dysfunction (POCD) in non-head trauma patients [31]. Several clinical investigations have proven that a single dose of ketamine $(0.5 \mathrm{mg} / \mathrm{Kg})$ at induction of anesthesia phase maybe attenuated postoperative cognitive dysfunction in patients undergoing cardiac surgery [31]. Additionally, they have demonstrated ketamine has a potential induction phase that reduces the incidence of postoperative delirium from $31 \%$ to $3 \%$ [31]. Thus, these beneficial effects of ketamine are thought to contribute to the mitigation of the postoperative systemic inflammatory response [31].

One study, in which patients reached a Ramsay Score 4-5 depth of anesthesia and had ketamine levels of $250-300 \mu \mathrm{g} / \mathrm{dL}$ for at least 4.5 days (i.e., in a medically-induced coma), reported that deep ketamine therapy was effective for relief of chronic pain and without harmful cognitive effects [32]. Studies have suggested that ketamine and other antidepressants mediate glutamate and neurotropic receptors [32]. This leads to a stimulation of the mammalian target of rapamycin (mTOR) pathway in the prefrontal cortex (PFC), thereby resulting in transient activation of the downstream effectors, such as $4 \mathrm{E}$-binding protein 1 and protein S6 kinase [32].

Significantly, the activation of mammalian target of rapamycin after ketamine administration would potentially indicate an association between significant deficits in synaptic proteins and dysregulation of the mammalian target of rapamycin pathway in patients with the major depressive disorder (MDD) [33,34]. Recently, some studies have focused on neuroinflammation and oxidative stress mechanisms in major depression [33,35]. For example, an agonist of peroxisome proliferator-activated receptor- $\alpha$ (PPAR- $\alpha$ ) was reported to inhibit neuroinflammation and oxidative stress, and it possessed the antidepressant-like effects of ketamine by preventing the neuroinflammation of many proteins that are involved in inflammation- related genes, including chemokine's and interferon-gamma-induced genes $[33,36,37]$.

\section{Dementia and Alzheimer's disease}

Ketamine is known as a noncompetitive N-methyl-D-aspartate receptor antagonist $[16,38,39]$. Therefore, administration of ketamine and other N-methyl-D-aspartate receptor antagonists, such as meantime, is used to improve the symptoms Alzheimer's disease (AD) [40]. Some studies have revealed (the excitotoxic hypothesis) that there are glutamatergic hyperactivity receptors in Alzheimer's disease. neuronal and astroglial glutamate transporter dysfunction in Alzheimer's disease may be lead to excess glutamate in the synaptic cleft and excitotoxicity neuronal damage [40,41]. In addition, in the hippocampus and the striatum, cholinergic neurons can control the liberation of acetylcholine [42]. Thus, in the prefrontal cortex, these cholinergic neurons would be mediated by nicotinic and muscarinic receptors $[42,43]$. Ketamine plays a vital role in the occurrence of psychic phenomena by a direct inhibiting effect on these receptors.

Additionally, ketamine may facilitate acetylcholine liberation in the hippocampus because the release of dopamine has increased. Clinically, sufficient concentrations of ketamine could inhibit acetylcholine liberation by $\mathrm{N}$-methyl-D-aspartate receptors and inhibit nicotinic receptors [44]. In addition, it has antagonist activity on muscarinic receptors [45]. The $\mathrm{N}$-methyl-D-aspartate receptor, blocked by ketamine for concentrations between 2 and $50 \mu \mathrm{m}$ intramuscular (IM), is responsible for ketamine's most essential pharmacological properties. Glutamate is the most prevalent amino acid in the central nervous system (CNS), involving glutamatergic synapses. N-methyl-D-aspartate receptors are present on nearly all the neural cells of the central nervous system, particularly in the structures implicated in nociception, such as primary afferents or spinal dorsal horn [46]. When glutamate is released in the synaptic cleft, there is an activation of the postsynaptic ionotropic receptors, which leads to the opening of ion channels, and is then responsible for a membrane depolarization.

Oxidative stress and protein damage are the processes related to the pathogenesis of Alzheimer's disease [47]. The hippocampus, which is mainly affected by Alzheimer's disease, is a significant structure for memory function of humans and spatial memory of rodents. Several studies have reported that a single sub-anesthetic dose of ketamine increases lipid peroxidation and protein damage in the hippocampus. It was shown that the hippocampus is involved in three stages of the memory mechanism: acquisition, consolidation, and retrieval. Therefore, considering ketamine-induced protein damage in the hippocampus, as well as its antagonism effect of N-methyl-Daspartate receptors, a study in mice was conducted to assess the impact of a sub-anesthetic dose of ketamine on those three stages [48]. The results showed that pre-training administration of a sub-anesthetic dose of ketamine deteriorates learning and pre-probe administration of ketamine impaired performance in the probe trial $[47,48]$. However, post-training administration of ketamine did not effect on the animals' performance. The study shows that sub-anesthetic ketamine could affect memory acquisition and retrieval, but does not reduce memory consolidation.

\section{Depression}

Antidepressant actions in animal models have been demonstrated with ketamine, as have rapid antidepressant effects in human studies $[49,50]$. Ketamine is a high-affinity N-methyl-D-aspartate receptor antagonist, which also binds to opioid $\mu$ and sigma receptor [51] 
Ketamine was reported to regulate dopamine transmission and reuptake [52,53]. Treatment-resistant depression affects over $1 \%$ of individuals in the United States, and nearly $30 \%$ of all depressed patients [54]. Ketamine has active and rapid antidepressant properties, so it is suggested for treating resistant depression (TRD). Ketamine may be considered as a novel pharmacological medication for managing both major depressive disorder and treatmentresistant depression (TRD) patients [55]. Ketamine's action is rapid in contrast to the delayed response of the currently available antidepressant agents, which require several weeks to produce an effect $[55,56]$

Several studies have provided highly valuable insight into the neural systems that are involved in the antidepressant effects of ketamine [57]. Indeed, the long-term beneficial actions of ketamine on depressive symptoms are noticeable; however, there is no current research available for addressing the long-term effect of a single-injection of ketamine on brain circuitry in major depressive disorder. To understand the vital role of the brain reward system in the pathophysiology of the major depressive disorder, we need to produce genetic evidence that suggests Brain-Derived Neurotrophic Factor (BDNF) plays a crucial role in this process.

However, the downstream signaling pathways, which mediate the actions of this neurotrophin, have been identified. A significant amount of experimental data demonstrates that ketamine can interact with the majority of cellular signaling pathways that are involved in major depressive disorder [57,58]. The antidepressant behavioral effects of ketamine were inhibited in conditional Brain-Derived Neurotrophic Factor deletion mutant mice, as well as after the infusion of a functionblocking anti-Brain-Derived Neurotrophic Factor antibody into the prefrontal cortex [59].
Ketamine has demonstrated antidepressant effects in patients with the major depressive disorder, and its results have been reported in several studies for treatment-resistant depression [60]. Preclinical studies have shown ketamine has antidepressant effects in some animal models of depression by expressing serine/threonine protein kinase. This is called the mammalian target of rapamycin, which modulates cell growth, proliferation, motility, survival, and protein synthesis. These observations have provided a mechanistic explanation of how decreased levels of Brain-Derived Neurotropic Factor and downstream mechanistic target of rapamycin complex 1 signaling, associated with depressive symptoms could be reversed via rapid-acting antidepressants, such as ketamine (Figure 1).

Pharmacologically, several studies that determine the concentration and administration speed-dependent effects of ketamine in depression are needed [61]. Recently, one study suggested that the results of ketamine on mood are dose-dependent. The investigators have recently compared the effects of $0.1-0.4 \mathrm{mg} / \mathrm{kg}$ of ketamine in patients with the major depressive disorder and found vast improvements were achieved at the highest dose level [62]. In addition, recent data suggest the effectiveness of ketamine in reducing suicidality and in alleviating posttraumatic stress disorder (PTSD) symptoms might also extend in parallel with its antidepressant effects.

\section{Acute brain injury}

The occurrence of traumatic brain injury is high; incidence is increased in developing countries and exceeds that of the developed world [63]. Therapeutic strategy for reducing traumatic brain injury or stroke after ischemia or trauma is well defined. The treatment is aimed at alleviating secondary damage, which occurs within hours to days after an acute brain insult. Neuroscientists and clinicians have struggled to identify the cause and consequences of this secondary

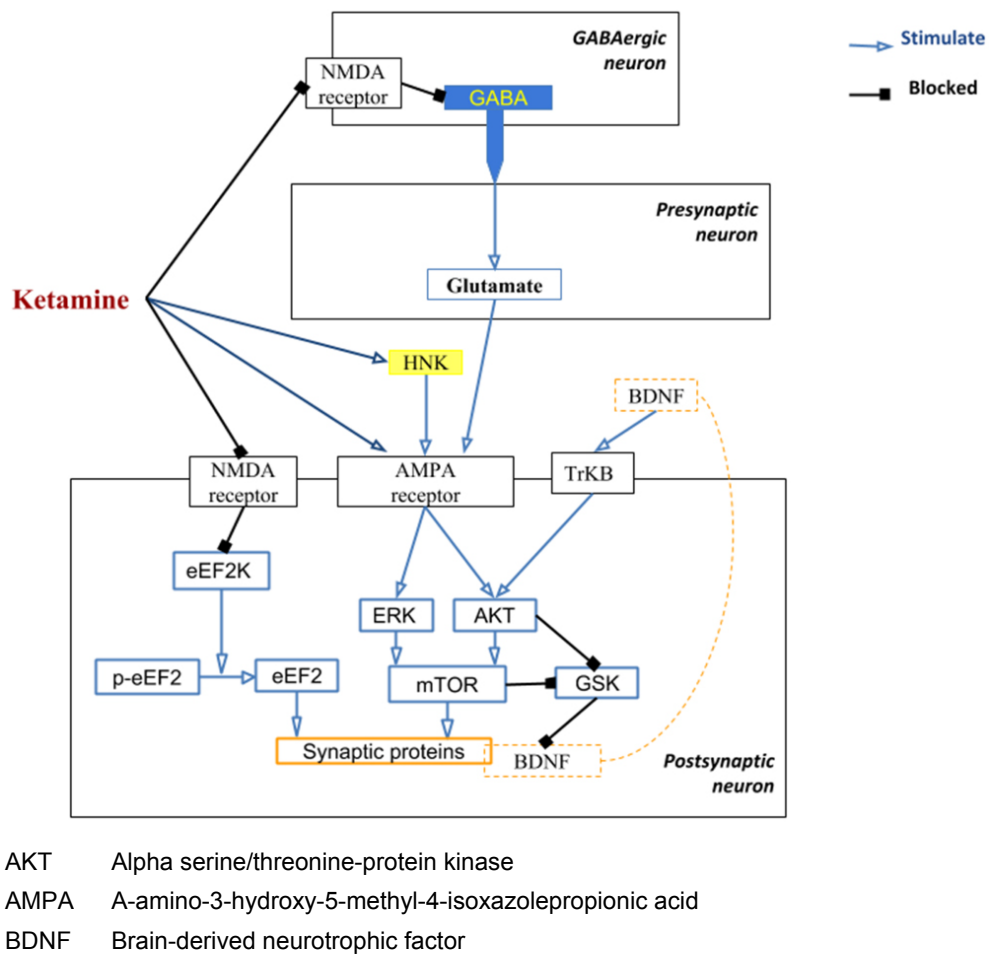

Figure 1: Modified and revised from; Vutskits L. General Anesthetics to Treat Major Depressive Disorder: Clinical Relevance and Underlying Mechanisms. 
damage [64]. Successful treatment of stroke and diffuse brain injury lies in understanding the complexity of the processes involved in perpetuating subsequent cell death, which requires a compound capable of mitigating each of these processes.

There was some concern regarding the use of ketamine in the neurosurgical and acute brain injury populations due to adverse effects, as it may increase intracranial pressure. More recently, reevaluation of the medication has shown this to be incorrect, particularly in patients on mechanical ventilation [65]. In 1996, ketamine was shown to reduce cell injury in axotomy of peripheral neurons and motoneurons in cell cultures [66]. This resulted in improving neuronal survival, by using experimental animal models of stroke and brain trauma to reduce neuronal discharge and damage as seen in status epilepticus [67-69]. Many studies have shown that using ketamine leads to minimized focal ischemia size and decreased volume of hemorrhagic necrosis in experimental head injury models. These preclinical investigations have determined that ketamine provides histopathologic and physiological neuroprotection across extended arrangements of acute neuroinjury models [70].

Additionally, research has shown that ketamine has a potent extrasynaptic antagonistic effect, extensively inhibiting stimulation of the selectively neurotoxic NR2B-containing N-methyl-D-aspartate receptors [71]. Ketamine has antiglutamatergic impacts that might have a role in the management of delayed cerebral ischemia following subarachnoid hemorrhage $(\mathrm{SAH})$ and cerebral vasospasm [72,73]. Therefore, ketamine may play a profound role in the reduction of glutamate-induced cell death.

\section{Immune system}

Ketamine reduces tissue necrosis factor $\alpha$ (TNF- $\alpha)$, interleukins (IL) and nitric oxide (NO) production, all of which play vital roles during the inflammatory process, and the inhibition of these activities could affect macrophage-mediated immunity [74]. The potential mechanism of ketamine-induced immunosuppression was studied to evaluate effects in macrophages, tissue necrosis factor $\alpha$, interleukins$1 \beta$, and interleukins- 6 messenger ribonucleic acid (mRNA) syntheses, and it was found that ketamine inhibited messenger ribonucleic acid syntheses by lipopolysaccharide (LPS)-activated macrophages. Ketamine has recently been used as an anti-inflammatory drug, which emphasizes the significance of research on its interactions with the immune system. Indeed, major surgery or sepsis leads to the release of proinflammatory mediators, including large amounts of cytokines, which can lead to undesirable effects, such as low blood pressure and multiple organ failures.

Moreover, ketamine has a double effect that connects both the analgesic and neuroprotective actions of its anti-inflammatory effects; ketamine regulates the inhibition of tumor necrosis factor $\alpha$, interleukin 6 and proinflammatory cytokine activities that would occur in both peripheral immune cells and glial cells in the central nervous system $[37,75]$. The primary protective inflammatory mechanism in the central nervous system in defense of brain injury is often rapidly deregulated in a cerebrovascular accident. For example, in stroke, as a result of excessive microglial activation with release of tissue necrosis factor $\alpha$ that leads to stimulation of the extrinsic apoptotic pathway, as well as interleukins- $1 \beta$, interleukins- 8 , and interleukins-6 $[74,76]$. This, in turn, might lead to enhance blood-brain barrier permeability, a process that allows inflammatory cells, such as monocytes, neutrophils, and lymphocytes to cross the blood-brain barrier into the central nervous system $[74,76,77]$.
More recently shown in the anti-inflammatory mechanism of ketamine is the inhibition of high mobility group box 1 (HMGB1) induced activation of endothelial cells $[78,79]$. High mobility group box 1 is considered as the main prototype of the emerging injuryassociated molecular proteins and indicator of host tissue damage $[80,81]$. The proinflammatory cytokine is released from endothelial cells, as well as leukocyte adhesion and transmigration, thus, elevated high mobility group box 1 levels could predict non-survivors in subarachnoid hemorrhage, which may be countered by improving neuroinflammation in subarachnoid hemorrhage [82,83]. Ketamine was shown to have an excessive inhibitory effect on high mobility group box 1-induced endothelial cell activation by a mechanism involving nuclear factor $\kappa \mathrm{B}$ and toll-like receptor $[79,82,84]$.

\section{Conclusion}

Much research has been conducted on ketamine's mechanisms of action; specifically those related to its anti-depressive effects, antiinflammatory effects, and chronic pain management and cognitive function. For testing long-term efficacy and safety of ketamine in nonanesthetic clinical practice for managing major resistant depression, enhancing memory function in Alzheimer's patients, and reducing the brain damage after stroke needed for further studies. This review provides evidence of the medical benefits of the non-anesthetic effects of ketamine, as well as supporting evidence of the effectiveness and tolerability of ketamine for managing chronic pain conditions.

\section{References}

1. Hocking G, Cousins MJ (2003) Ketamine in chronic pain management: an evidence-based review. Anesth Analg 97: 1730-1739.

2. Reves JG, Lubarsky DA, McEvoy MD, Ruiz RM (2014) Intravenous Anesthetics.

3. Stone J, Fawcett W (2013) Anaesthesia at a glance. John Wiley 2013: 1-10.

4. Sigtermans MJ, Van Hilten JJ, Bauer MC, Arbous MS, Marinus J (2009) Ketamine produces effective and long-term pain relief in patients with Complex Regional Pain Syndrome Type 1. Pain 145: 304-311.

5. Maddox RP, Seupaul RA (2014) Is ketamine effective for the management of acute asthma exacerbations in children? Ann Emerg Med 63: 309-310.

6. Agrawal A, Shrivastava J (2014) Intravenous Ketamine for Refractory Bronchospasm Precipitated by H1N1 Infection. Front Pediatr 2: 24-28.

7. Garg D, Kaistha S, Sood D (2011) Subanaesthetic dose of ketamine in intractable asthma. J Indian Med Assoc 109: 430-434.

8. Kvarnstrom A, Karlsten R, Quiding H, Emanuelsson BM, Gordh T (2003) The effectiveness of intravenous ketamine and lidocaine on peripheral neuropathic pain. Acta Anaesthesiol Scand 47: 868-877

9. Christo PJ, Hobelmann G, Maine DN (2007) Post-herpetic neuralgia in older adults: evidence-based approaches to clinical management. Drugs Aging 24 $1-19$.

10. Brown TC, Cole WH, Murray GH (1970) Ketamine: A new anaesthetic agent Aust N Z J Surg 39: 305-310.

11. Lim DK (2003) Ketamine associated psychedelic effects and dependence. Singapore Med J 44: 31-34.

12. Perel A, Davidson JT (1976) Recurrent hallucinations following ketamine Anaesthesia 31: 1081-1083.

13. Powers AR, Gancsos MG, Finn ES, Morgan PT, Corlett PR (2015) KetamineInduced Hallucinations. Psychopathology 48: 376-85.

14. Sigtermans M, Dahan A, Mooren R, Bauer M, Kest B, et al. (2009) S(+)-ketamine effect on experimental pain and cardiac output: a population pharmacokineticpharmacodynamic modeling study in healthy volunteers. Anesthesiology 111 : 892-903.

15. Herd DW, Anderson BJ, Keene NA, Holford NH (2008) Investigating the pharmacodynamics of ketamine in children. Paediatr Anaesth 18: 36-42. 
Citation: Eldufani J, Nekoui A, Blaise G (2018) Non-Anesthetic Effects of Ketamine: A Review Article Authors. J Health Med Informat 9: 311 . doi: 10.4172/2157-7420.1000311

Page 5 of 6

16. Kohrs R, Durieux ME (1998) Ketamine: teaching old drug new tricks. Anesth Analg 87: 1186-1193.

17. Dinakar P, Stillman AM (2016) Pathogenesis of Pain. Semin Pediatr Neurol 23: 201-8.

18. Vutskits L, Gascon E, Tassonyi E, Kiss JZ (2006) Effect of ketamine on dendritic arbor development and survival of immature GABAergic neurons in vitro. Toxicol Sci 91: 540-549.

19. Schnoebel R, Wolff M, Peters SC, Brau ME, Scholz A, et al. (2005) Ketamine impairs excitability in superficial dorsal horn neurones by blocking sodium and voltage-gated potassium currents. Br J Pharmacol 146: 826-833.

20. Grieco SF, Velmeshev D, Magistri M, Eldar-Finkelman H, Faghihi MA, et al. (2017) Ketamine up-regulates a cluster of intronic miRNAs within the serotonin receptor $2 \mathrm{C}$ gene by inhibiting glycogen synthase kinase-3. World $\mathrm{J}$ Biol Psychiatry 18: 445-456.

21. Stenovec M, Lasic E, Bozic M, Bobnar ST, Stout RF, et al. (2016) Ketamine Inhibits ATP-Evoked Exocytotic Release of Brain-Derived Neurotrophic Factor from Vesicles in Cultured Rat Astrocytes. Mol Neurobiol 53: 6882-6896.

22. Liebenberg N, Joca S, Wegener G (2015) Nitric oxide involvement in the antidepressant-like effect of ketamine in the Flinders sensitive line rat model of depression. Acta Neuropsychiatr 27: 90-96.

23. Shimaoka M, lida T, Ohara A, Taenaka N, Mashimo T, et al. (1996) Ketamine inhibits nitric oxide production in mouse-activated macrophage-like cells. $\mathrm{Br} \mathrm{J}$ Anaesth 77: 238-242.

24. Maher DP, Chen L, Mao J (2017) Intravenous Ketamine Infusions for Neuropathic Pain Management: A Promising Therapy in Need of Optimization. Anesth Analg 124: 661-674

25. Do Vale EM, Xavier CC, Nogueira BG, Campos BC, de Aquino PE, et al. (2016) Antinociceptive and Anti-Inflammatory Effects of Ketamine and the Relationship to Its Antidepressant Action and GSK3 Inhibition. Basic Clin Pharmacol Toxicol 119: 562-573.

26. Woolf CJ, Salter MW (2000) Neuronal plasticity: increasing the gain in pain. Science 288: 1765-1769.

27. Niesters M, Martini C, Dahan A (2014) Ketamine for chronic pain: risks and benefits. Br J Clin Pharmacol 77: 357-367.

28. Pak DJ, Yong RJ, Kaye AD, Urman RD (2018) Chronification of Pain Mechanisms, Current Understanding, and Clinical Implications. Curr Pain Headache Rep 22: 9-14.

29. Lemke KA, Creighton CM (2010) Analgesia for anesthetized patients. Top Companion Anim Med 25: 70-82.

30. Liu FL, Chen TL, Chen RM (2012) Mechanisms of ketamine-induced immunosuppression. Acta Anaesthesiol Taiwan 50: 172-177.

31. Bell JD (2017) In Vogue: Ketamine for Neuroprotection in Acute Neurologic Injury. Anesth Analg 124: 1237-1243.

32. Koffler SP, Hampstead BM, Irani F, Tinker J, Kiefer RT, et al. (2007) The neurocognitive effects of 5 day aesthetic ketamine for the treatment of refractory complex regional pain syndrome. Arch Clin Neuropsychol 22: 719-729.

33. Reus GZ, Nacif MP, Abelaira HM, Tomaz DB, Dos Santos MA, et al. (2015) Ketamine treatment partly reverses alterations in brain derived-neurotrophic factor, oxidative stress and energy metabolism parameters induced by an animal model of depression. Curr Neurovasc Res 12: 73-84.

34. De Vry J, Jentzsch KR (2003) Role of the NMDA receptor NR2B subunit in the discriminative stimulus effects of ketamine. Behav Pharmacol 14: 229-235.

35. Felger JC, Lotrich FE (2013) Inflammatory cytokines in depression: neurobiological mechanisms and therapeutic implications. Neuroscience 246 199-229.

36. Abelaira HM, Reus GZ, Ignacio ZM, Dos Santos MA, de Moura AB, et al. (2017) Effects of ketamine administration on mTOR and reticulum stress signaling pathways in the brain after the infusion of rapamycin into prefrontal cortex. J Psychiatr Res 87: 81-87.

37. Spentzas T, Shapley RK, Aguirre CA, Meals E, Lazar L, et al. (2011) Ketamine inhibits tumor necrosis factor secretion by RAW264.7 murine macrophages stimulated with antibiotic-exposed strains of community-associated, methicillinresistant Staphylococcus aureus. BMC Immunol 12: 11.
38. Anis NA, Berry SC, Burton NR, Lodge D (1983) The dissociative anaesthetics, ketamine and phencyclidine, selectively reduce excitation of central mammalian neurones by N-methyl-aspartate. Br J Pharmacol 79: 565-575.

39. Yamakura T, Mori H, Masaki H, Shimoji K, Mishina M (1993) Different sensitivities of NMDA receptor channel subtypes to non-competitive antagonists. Neuroreport 4: 687-690.

40. Masliah E, Alford M, DeTeresa R, Mallory M, Hansen L (1996) Deficient glutamate transport is associated with neurodegeneration in Alzheimer's disease. Ann Neurol 40: 759-766.

41. Li S, Mallory M, Alford M, Tanaka S, Masliah E (1997) Glutamate transporter alterations in Alzheimer disease are possibly associated with abnormal APP expression. J Neuropathol Exp Neurol 56: 901-911.

42. Toro-Matos A, Rendon-Platas AM, Avila-Valdez E, Villarreal-Guzman RA (Physostigmine antagonizes ketamine) Physostigmine antagonizes ketamine Anesth Analg 59: 764-767.

43. Kubota T, Hirota K, Anzawa N, Yoshida H, Kushikata T, et al. (1999) Physostigmine antagonizes ketamine-induced noradrenaline release from the medial prefrontal cortex in rats. Brain Res 840: 175-178.

44. Furuya R, Oka K, Watanabe I, Kamiya Y, Itoh H, et al. (1999) The effects of ketamine and propofol on neuronal nicotinic acetylcholine receptors and P2x purinoceptors in PC12 cells. Anesth Analg 88: 174-180.

45. Durieux ME (1995) Inhibition by ketamine of muscarinic acetylcholine receptor function. Anesth Analg 81: 57-62.

46. Greenamyre JT, Porter RH (1994) Anatomy and physiology of glutamate in the CNS. Neurology 44: S7-13.

47. Rosenbrock H D-CC, Kroker K, Rast G (2011) Effects of specific nicotinic acetylcholine receptor agonists on hippocampal long-term potentiation. Alzheimer's \& Dementia. J Alzhe Assoc 7: S116.

48. Moosavi M, Yadollahi Khales G, Rastegar K, Zarifkar A (2012) The effect of sub-anesthetic and anesthetic ketamine on water maze memory acquisition, consolidation and retrieval. Eur J Pharmacol. 677: 107-110.

49. Serafini G, Howland RH, Rovedi F, Girardi P, Amore M (2014) The role of ketamine in treatment-resistant depression: a systematic review. Cur Neuropharmacol 12: 444-461.

50. Monteggia LM, Zarate C Jr (2015) Antidepressant actions of ketamine: from molecular mechanisms to clinical practice. Curr Opin Neurobiol 30: 139-143.

51. Autry AE, Adachi M, Nosyreva E, Na ES, Los MF, et al. (2011) NMDA recepto blockade at rest triggers rapid behavioural antidepressant responses. Nature 475: 91-95.

52. Krystal JH, Perry EB, Jr Gueorguieva R, Belger A, Madonick SH, et al. (2005) Comparative and interactive human psychopharmacologic effects of ketamine and amphetamine: Implications for glutamatergic and dopaminergic model psychoses and cognitive function. Arch Gen Psychiatry 62: 985-994.

53. Vollenweider FX, Vontobel P, Oye I, Hell D, Leenders KL (2000) Effects of (S)-ketamine on striatal dopamine: A [11C]raclopride PET study of a model psychosis in humans. J Psychiatr Res 34: 35-43.

54. Rush AJ, Trivedi MH, Wisniewski SR, Nierenberg AA, Stewart JW, et al. (2006) Acute and longer-term outcomes in depressed outpatients requiring one or several treatment steps: a Star D report. Am J Psychiatry 163: 1905-1917.

55. Duncan WC, Selter J, Brutsche N, Sarasso S, Zarate CA (2013) Baseline delta sleep ratio predicts acute ketamine mood response in major depressive disorder. J Affect Disord 145: 115-119.

56. Murrough JW, losifescu DV, Chang LC, Al Jurdi RK, Green CE, et al. (2013) Antidepressant efficacy of ketamine in treatment-resistant major depression: two-site randomized controlled trial. Am J Psychiatry 170: 1134-1142.

57. Duman CH, Duman RS (2015) Spine synapse remodeling in the pathophysiology and treatment of depression. Neurosci Lett 601: 20-29.

58. Nosyreva E, Autry AE, Kavalali ET, Monteggia LM (2014) Age dependence of the rapid antidepressant and synaptic effects of acute NMDA receptor blockade. Front Mol Neurosci 7: 94

59. Lepack AE, Fuchikami M, Dwyer JM, Banasr M, Duman RS (2014) BDNF release is required for the behavioral actions of ketamine. Int $\mathrm{J}$ Neuropsychopharmacol 2014: 18. 
Citation: Eldufani J, Nekoui A, Blaise G (2018) Non-Anesthetic Effects of Ketamine: A Review Article Authors. J Health Med Informat 9: 311 . doi: 10.4172/2157-7420.1000311

Page 6 of 6

60. Yang R, Wang P, Chen Z, Hu W, Gong Y, et al. (2017) WY-14643, a selective agonist of peroxisome proliferator-activated receptor-alpha, ameliorates lipopolysaccharide-induced depressive-like behaviors by preventing neuroinflammation and oxido-nitrosative stress in mice. Pharmacol Biochem Behav 153: 97-104.

61. Lai R, Katalinic N, Glue P, Somogyi AA, Mitchell PB, et al. (2014) Pilot doseresponse trial of ketamine in treatment-resistant depression. World $\mathrm{J}$ Biol Psychiatry 15: 579-584

62. Vutskits L (2018) General Anesthetics to Treat Major Depressive Disorder: Clinical Relevance and Underlying Mechanisms. Anesth Analg 126: 208-216.

63. Mock C, Quansah R, Krishnan R, Arreola-Risa C, Rivara F (2004) Strengthening the prevention and care of injuries worldwide. Lancet 363: 2172-2179.

64. Hijazi Y, Bodonian C, Bolon M, Salord F, Boulieu R (2003) Pharmacokinetics and haemodynamics of ketamine in intensive care patients with brain or spinal cord injury. Br J Anaesth 90: 155-160.

65. Filanovsky Y, Miller P, Kao J (2010) Myth: Ketamine should not be used as an induction agent for intubation in patients with head injury. CJEM 12: 154-157.

66. Himmelseher S, Pfenninger E, Georgieff M (1996) The effects of ketamineisomers on neuronal injury and regeneration in rat hippocampal neurons. Anesth Analg 83: 505-512.

67. Fujikawa DG (1995) Neuroprotective effect of ketamine administered after status epilepticus onset. Epilepsia 36: 186-195.

68. Tang SH, Yu JG, Li JJ, Sun JY (2015) Neuroprotective effect of ketamine on acute spinal cord injury in rats. Genet Mol Res 14: 3551-356.

69. Hoffman WE, Pelligrino D, Werner C, Kochs E, Albrecht RF, et al. (1992) Ketamine decreases plasma catecholamines and improves outcome from incomplete cerebral ischemia in rats. Anesthesiology 76: 755-762.

70. Shapira Y, Lam AM, Eng CC, Laohaprasit V, Michel M (1994) Therapeutic time window and dose response of the beneficial effects of ketamine in experimental head injury. Stroke 25: 1637-1643.

71. Miller OH, Yang L, Wang CC, Hargroder EA, Zhang Y, et al. (2014) GluN2Bcontaining NMDA receptors regulate depression-like behavior and are critical for the rapid antidepressant actions of ketamine. Elife 3: e03581.

72. Jung CS, Lange B, Zimmermann M, Seifert V (2013) CSF and Serum Biomarkers Focusing on Cerebral Vasospasm and Ischemia after Subarachnoid Hemorrhage. Stroke Res Treat 2013: 560305.
73. Saveland H, Nilsson OG, Boris-Moller F, Wieloch T, Brandt L (1996) Intracerebral microdialysis of glutamate and aspartate in two vascular territories after aneurysmal subarachnoid hemorrhage. Neurosurgery 38: 12-9.

74. Beilin B, Rusabrov Y, Shapira Y, Roytblat L, Greemberg L, et al. (2007) Low-dose ketamine affects immune responses in humans during the early postoperative period. Br J Anaesth 99: 522-527.

75. Liu F-L, Chen T-L, Chen R-M (2012) Mechanisms of ketamine-induced immunosuppression. Acta Anaesthesiologica Taiwanica 50: 172-177.

76. Shaked G, Czeiger D, Dukhno O, Levy I, Artru AA, et al. (2004) Ketamine improves survival and suppresses IL-6 and TNFalpha production in a model of Gram-negative bacterial sepsis in rats. Resuscitation 62: 237-242.

77. Shibakawa YS, Sasaki Y, Goshima Y, Echigo N, Kamiya Y, et al. (2005) Effects of ketamine and propofol on inflammatory responses of primary glial cell cultures stimulated with lipopolysaccharide. $\mathrm{Br} \mathrm{J}$ Anaesth 95: 803-810.

78. Tan $Y$, Wang Q, She $Y$, Bi X, Zhao B (2015) Ketamine reduces LPS-induced HMGB1 via activation of the Nrf2/HO-1 pathway and NF-kappaB suppression. $\mathrm{J}$ Trauma Acute Care Surg 78: 784-792.

79. Liu Z, Wang Z, Han G, Huang L, Jiang J, et al. (2016) Ketamine attenuates high mobility group box-1-induced inflammatory responses in endothelial cells. J Surg Res 200: 593-603.

80. Palumbo R, Sampaolesi M, De Marchis F, Tonlorenzi R, Colombetti S et al. (2004) Extracellular HMGB1, a signal of tissue damage, induces mesoangioblast migration and proliferation. J Cell Biol 164: 441-449.

81. Lotze MT, Tracey KJ (2005) High-mobility group box 1 protein (HMGB1) nuclear weapon in the immune arsenal. Nat Rev Immunol 5: 331-342.

82. Sun Q, Wu W, Hu YC, Li H, Zhang D, et al. (2014) Early release of high-mobility group box 1 (HMGB1) from neurons in experimental subarachnoid hemorrhage in vivo and in vitro. J Neuroinflammation 11: 106.

83. Hayakawa K, Qiu J, Lo EH (2010) Biphasic actions of HMGB1 signaling in inflammation and recovery after stroke. Ann N Y Acad Sci 1207: 50-57.

84. Sokol B, Wozniak A, Jankowski R, Jurga S, Wasik N, et al. (2015) HMGB1 Level in Cerebrospinal Fluid as a Marker of Treatment Outcome in Patients with Acute Hydrocephalus Following Aneurysmal Subarachnoid Hemorrhage. J Stroke Cerebrovasc Dis 24: 1897-1904. 